\title{
Teaching Video NeuroImages: A Triad of Tremor, Ataxia, and Cognitive Impairment
}

Lisa W.C. Au, FHKAM, Ko Ho, PhD, Joshua J.X. Li, MBChB, and Vincent C.T. Mok, MD

Neurology ${ }^{\circledR}$ 2021;96:e1802-e1803. doi:10.1212/WNL.0000000000011288

Figure 1 MRI Brain

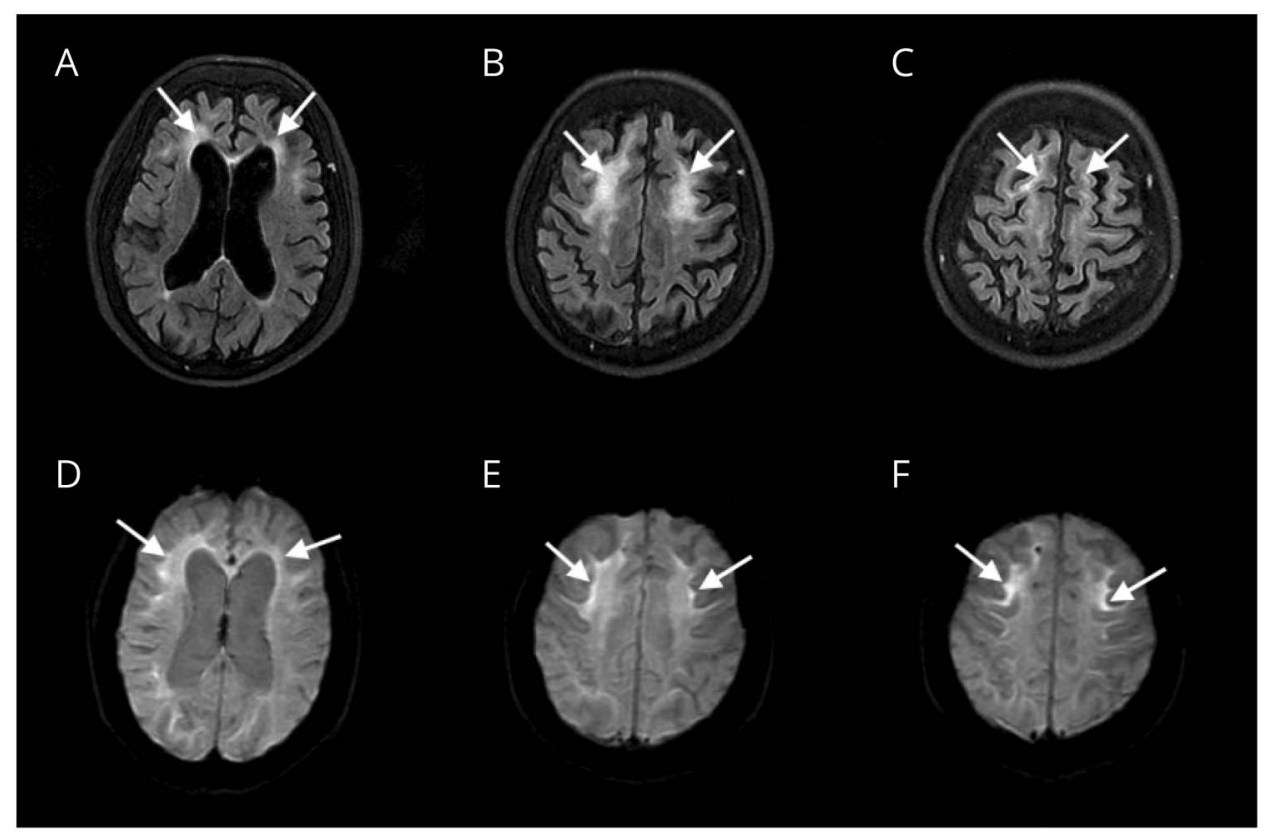

Axial MRI brain performed at age 72 years showed bilateral subcortical white matter lesions (arrows) on axial fluidattenuated inversion recovery images (A-C) and high signal intensity along the corticomedullary junction (arrows) on diffusion-weighted images (D-F).

A 67-year-old woman presented with a 2-year history of forgetfulness and unsteadiness. She scored 17 on the Montreal Cognitive Assessment. She had tremor of head and upper limbs (video 1) since early adulthood, which was diagnosed as essential tremor. Brain MRI showed leukoencephalopathy and high signal intensity along the corticomedullary junction on diffusion-weighted images (figure 1). The diagnosis of adult-onset neuronal intranuclear inclusion disease (NIID) was confirmed by skin biopsy showing eosinophilic intranuclear inclusions (figure 2). ${ }^{1}$ NIID is a clinically heterogeneous rare neurodegenerative disease. ${ }^{2}$ Its characteristic MRI pattern should prompt confirmation of the diagnosis by skin biopsy.

\section{Study Funding}

No targeted funding reported.

\section{Disclosure}

The authors report no disclosures relevant to the manuscript. Go to Neurology.org/N for full disclosures.
Correspondence

Lisa Wing Chi Au

lisaau@cuhk.edu.hk
MORE ONLINE

\section{- Video}

\section{$\rightarrow$ Teaching slides}

links.lww.com/WNL/

B293

From the Departments of Medicine and Therapeutics (L.W.C.A., K.H., V.C.T.M.) and Anatomical and Cellular Pathology (I.J.X.L.), The Chinese University of Hong Kong, Prince of Wales Hospital; and Gerald Choa Neuroscience Centre, Margaret K.L. Cheung Research Centre for Management of Parkinsonism (L.W.C.A., K.H., V.C.T.M.), Therese Pei Fong Chow Research Centre for Prevention of Dementia, Hong Kong.

Go to Neurology.org/N for full disclosures. 

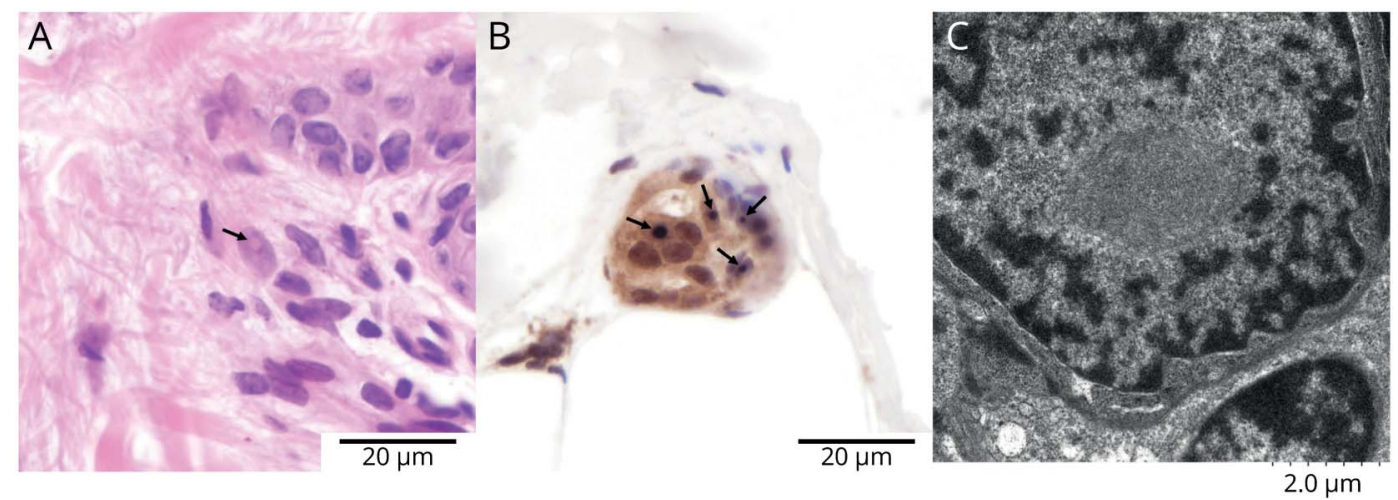

Hematoxylin \& eosin stain of fibroblasts (A) and ubiquitin immunostain of sweat gland cells (B) showing intranuclear inclusions (arrows); the inclusions consisted of electron-dense filamentous materials without membrane structure on electron microscopy (C).

\section{Appendix Authors}

\begin{tabular}{lll}
\hline Name & Location & Contribution \\
\hline $\begin{array}{l}\text { Lisa W.C. } \\
\text { Au, FHKAM }\end{array}$ & $\begin{array}{l}\text { The Chinese } \\
\text { University of Hong } \\
\text { Kong }\end{array}$ & $\begin{array}{l}\text { Designed and conceptualized study, } \\
\text { analyzed the data, drafted the } \\
\text { manuscript for intellectual content }\end{array}$ \\
\hline Ko Ho, PhD & $\begin{array}{l}\text { The Chinese } \\
\text { University of Hong } \\
\text { Kong }\end{array}$ & Interpreted the data \\
\hline $\begin{array}{l}\text { Joshua J.X. } \\
\text { Li, MBChB }\end{array}$ & $\begin{array}{l}\text { The Chinese } \\
\text { University of Hong } \\
\text { Kong }\end{array}$ & Interpreted the data \\
\hline
\end{tabular}

\begin{tabular}{lll} 
Appendix & (continued) & \\
\hline Name & Location & Contribution \\
\hline $\begin{array}{ll}\text { Vincent } \\
\text { C.T. Mok, } \\
\text { MD }\end{array}$ & $\begin{array}{l}\text { The Chinese } \\
\text { Konersity of Hong }\end{array}$ & $\begin{array}{l}\text { Interpreted the data, revised the } \\
\text { manuscript for intellectual content }\end{array}$ \\
\hline
\end{tabular}

\section{References}

1. Sone J, Tanaka F, Koike H, et al. Skin biopsy is useful for the antemortem diagnosis of neuronal intranuclear inclusion disease. Neurology 2011;76:1372-1376.

2. Sone J, Mori $\mathrm{K}$, Inagaki $\mathrm{T}$, et al. Clinicopathological features of adult-onset neuronal intranuclear inclusion disease. Brain 2016;139:3170-3186. 


\section{Neurology}

Teaching Video NeuroImages: A Triad of Tremor, Ataxia, and Cognitive Impairment Lisa W.C. Au, Ko Ho, Joshua J.X. Li, et al.

Neurology 2021;96;e1802-e1803 Published Online before print December 4, 2020

DOI 10.1212/WNL.0000000000011288

This information is current as of December 4, 2020

Updated Information \&
Services

References

Subspecialty Collections

Permissions \& Licensing

Reprints including high resolution figures, can be found at: http://n.neurology.org/content/96/13/e1802.full

This article cites 2 articles, 1 of which you can access for free at: http://n.neurology.org/content/96/13/e1802.full\#ref-list-1

This article, along with others on similar topics, appears in the following collection(s):

All Cognitive Disorders/Dementia

http://n.neurology.org/cgi/collection/all_cognitive_disorders_dementia DWI

http://n.neurology.org/cgi/collection/dwi

Gait disorders/ataxia

http://n.neurology.org/cgi/collection/gait_disorders_ataxia

Leukodystrophies

http://n.neurology.org/cgi/collection/leukodystrophies

Tremor

http://n.neurology.org/cgi/collection/tremor

Information about reproducing this article in parts (figures,tables) or in its entirety can be found online at:

http://www.neurology.org/about/about_the_journal\#permissions

Information about ordering reprints can be found online:

http://n.neurology.org/subscribers/advertise

Neurology ${ }^{\circledR}$ is the official journal of the American Academy of Neurology. Published continuously since 1951, it is now a weekly with 48 issues per year. Copyright (C) 2020 American Academy of Neurology. All rights reserved. Print ISSN: 0028-3878. Online ISSN: 1526-632X.

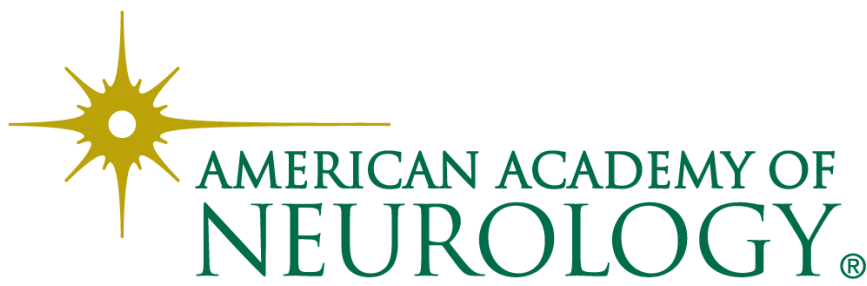

